\title{
Medievalista
}

Online

15 | 2014

Número 15

\section{Ralf Gottschlich, Das Kloster Santa Maria da Vitória in} Batalha

\section{Virgolino Ferreira Jorge}

\section{(2) OpenEdition}

1 Journals

\section{Edição electrónica}

URL: http://journals.openedition.org/medievalista/313

DOI: $10.4000 /$ medievalista.313

ISSN: 1646-740X

\section{Editora}

Instituto de Estudos Medievais - FCSH-UNL

\section{Refêrencia eletrónica}

Virgolino Ferreira Jorge, "Ralf Gottschlich, Das Kloster Santa Maria da Vitória in Batalha », Medievalista [Online], 15 | 2014, posto online no dia 01 janeiro 2014, consultado o 22 setembro 2020. URL : http:// journals.openedition.org/medievalista/313; DOI : https://doi.org/10.4000/medievalista.313

Mediavalista está licenciado com uma Licença Creative Commons - Atribuição-NãoComercial 4.0 Internacional. 
Título: Recensão a: GOTTSCHLICH, Ralf - Das Kloster Santa Maria da Vitória in Batalha. Hildesheim: Georg Olms Verlag, 2012. ISBN 978-3-487-14786-4

Autor(es): Virgolino Ferreira Jorge

Faculdade e Departamento / Unidade de Investigação: Universidade de Évora

Código Postal: 7000-849 ÉVORA

Cidade: Évora

País: Portugal

Contacto: vfjorge@gmail.com

Fonte: Medievalista [Em linha]. №15, (Janeiro - Junho 2014). Dir. José Mattoso. Lisboa: IEM.

Disponível em: http://www2.fcsh.unl.pt/iem/medievalista/ ISSN: 1646-740X

Data do texto: 27 de Março de 2013 


\title{
Recensão
}

\author{
GOTTSCHLICH, Ralf - Das Kloster Santa Maria da Vitória in Batalha. \\ Hildesheim: Georg Olms Verlag, 2012. ISBN 978-3-487-14786-4 \\ Virgolino Ferreira Jorge
}

Este estudo monográfico sobre a arquitectura do Convento de Santa Maria da Vitória na Batalha resulta de uma tese de doutoramento em História da Arte, apresentada e defendida pelo autor na Universidade Técnica de Dresden (Alemanha), no ano de 2002.

Com agrado, verifica-se que o importante complexo conventual batalhino - "centro" da arquitectura sacra gótica do país - continua a merecer o empenho e a atenção privilegiados de investigadores estrangeiros, que ampliam a bibliografia do monumento noutras línguas e promovem a sua leitura no mundo científico. Entre vários contributos anteriores a atestar esse sucesso, refiram-se os trabalhos de natureza histórico-artística e arquitectónica do inglês James Murphy, do francês Jean-Marie Guillouët e do alemão Ralf Gottschlich, cuja obra agora é recenseada.

O interesse do livro de Gottschlich é múltiplo, devido à visão ampla e à análise pormenorizada que oferece do monumento, descrito com uma riqueza de informação artística e de conhecimento técnico, muito úteis e pouco comuns entre os nossos historiadores da arte. Ao longo de 367 páginas ilustradas com fotografias e plantas, o autor apresenta o estado actual da investigação histórica e arquitectónica do conjunto dominicano batalhino, dá uma leitura renovada e sistemática dos edifícios conventuais e aprofunda alguns eixos de pesquisa acerca da nossa cultura artística de finais da Idade Média religiosa.

Perante a impossibilidade de comentar, de modo extenso, a estrutura e o conteúdo da publicação de Ralf Gottschlich, organizada em três partes principais, compostas por vários capítulos, assinalam-se, unicamente, alguns dos aspectos considerados de maior 
importância ou pertinência e que permitem aferir a justeza deste estudo. Ao leitor atento caberá descobrir ou avaliar outros interesses do trabalho em apreciação, susceptíveis de conferir mais valor e significado àquele monumento dominicano.

A realidade nacional dos séculos XIV-XVI e as condições sociopolíticas e económicas sob as quais surgiu e evoluiu este importante conjunto arquitectónico são retratadas e sintetizadas na parte inicial do estudo (págs. 1-53). A autoria e a responsabilidade de execução ou de condução das diversas obras batalhinas são aqui também discutidas. Julga-se que o tratamento desta matéria, que inclui a atribuição documentada das diferentes campanhas a onze mestres-de-obras, seria mais lógico e pedagógico se fosse apresentado e analisado com ulterioridade, num dos capítulos finais do livro. Com efeito, as notícias referentes à formação ou à origem geográfica e social desses construtores permitiriam, então, com outras achegas adicionais, interpretar ou entender, melhor e mais adequadamente, o tempo histórico e as circunstâncias de planificação e de laboração das várias fases da obra, o gosto e o poder régios, a circulação de influências artísticas, as linguagens formais do monumento e as respectivas concepções. A mesma opinião, e por motivos idênticos, vale para as referências aos trabalhos de conservação e restauro efectuados durante os séculos XIX e XX, cuja descrição e justificação parecem deslocadas aqui, nestes capítulos iniciais da monografia.

A segunda parte do livro (págs. 58-285) abre com a leitura exterior e interior da igreja, inserindo-se nesta última os factores principais da planta, seguidos da sua análise métrica e proporcional. Este tema da medida e do número na arquitectura ainda está muito pouco estudado entre nós, não obstante a sua utilidade fundamental para o entendimento da construção durante a Idade Média. A este propósito, afigura-se mais coerente que no "scanner" metodológico e didáctico de uma obra de arquitectura a análise da organização espacial da planta deverá preceder a descrição e a leitura morfológica dos alçados, na qual eles radicam. Esta parte intermédia do volume inclui, igualmente, um ensaio de cronologia relativa das obras e a explicação arquitectónica do claustro real e dos espaços habitacionais circundantes, da Capela do Fundador e das chamadas Capelas Imperfeitas.

A terceira e última parte da publicação (págs. 289-333) é dedicada ao enquadramento do conjunto dominicano da Batalha na arquitectura sacra da Península Ibérica, numa perspectiva crítica entre a tradição e a inovação verificadas ao longo dos séculos XIII a 
XV. Acredita-se que, nalguns aspectos particulares, embora comummente aceites mas nem sempre explícitos ou justificados, talvez haja um excesso de interpretação e o contributo da arquitectura religiosa nacional poderia ter sido mais explorado ou assumido e valorizado, quanto à sua afinidade ou apropriação.

O exame metódico e reflexivo efectuado às construções do antigo convento batalhino apoia-se na utilização de uma bibliografia abundante ${ }^{1}$, em muitas notas documentadas e numa vasta iconografia de acompanhamento, objectivando um texto esclarecedor e abalizado da arquitectura do régio conjunto dominicano. No olhar e no discurso de Gottschlich são visíveis as preocupações e os esforços para identificar e discutir os assuntos de pesquisa e de decifração crítica mais sensíveis deste monumento religioso e, com capacidade hermenêutica, propor hipóteses ou soluções explicativas acerca dessas dificuldades ou questionamentos.

A planta desdobrável do Convento da Batalha, apresentada em apêndice, contém informação limitada e insuficiente para o correcto julgamento bidimensional da sexcentenária construção, mormente para o leitor-utilizador que não conheça bem aquele magno e singular edifício.

Com esta monografia académica, o nosso autor melhorou e acrescentou saberes para uma compreensão mais epistemológica do conjunto de Santa Maria da Vitória na Batalha. Em simultâneo, o livro de Ralf Gottschlich convoca a atenção e desperta o surgimento de investigadores para uma época significativa e criativa da história e da arte nacionais, rasgando novos horizontes de estudo e favorecendo a integração, mais alargada e reconhecida, do património arquitectónico do nosso país no vasto contexto cultural e artístico europeu.

\footnotetext{
${ }^{1}$ Entretanto, há a acrescentar algumas publicações acerca do antigo convento dominicano da Batalha, saídas após a investigação principal de Gottschlich e que merecem referência: GUILLOUËT, Jean-Marie - Le portail de Santa Maria da Vitória de Batalha et l'art européen de son temps/O portal de Santa Maria da Vitória da Batalha e a arte do seu tempo. Leiria: Textiverso, 2011; MONTEIRO, António de Almeida - $O$ voto de el-rei D. João I antes da batalha real. Coimbra: Gráfica de Coimbra, 2011; REDOL, Pedro - O Mosteiro da Batalha e o vitral em Portugal nos sécs. XV e XVI. Batalha: Câmara Municipal da Batalha, 2003, e SOARES, Clara Moura - O restauro do Mosteiro da Batalha. Leiria: Magno Edições, 2001.
} 


\section{COMO CITAR ESTE ARTIGO}

\section{Referência electrónica:}

JORGE, Virgolino Ferreira, “[Recensão a] GOTTSCHLICH, Ralf - Das Kloster Santa Maria da Vitória in Batalha. Hildesheim: Georg Olms Verlag, 2012. ISBN 978-3-48714786-4“. Medievalista [Em linha]. №15, (Janeiro - Junho 2014). [Consultado dd.mm.aaaa]. Disponível em http://www2.fcsh.unl.pt/iem/medievalista/MEDIEVALISTA15/jorge1507.html.

ISSN 1646-740X.

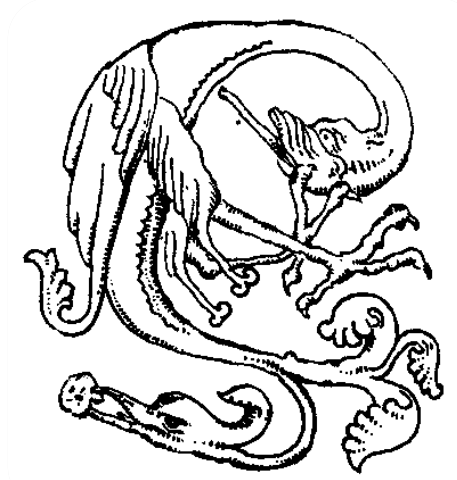

